\title{
Plant vascular development - connective tissue connecting scientists. Updates and trends at the PVB2013 conference
}

Raili Ruonala, Eva Hellmann, and Ykä Helariutta

Institute of Biotechnology/Department of Biosciences, University of Helsinki, Helsinki, Finland

In July 2013, the scientific community fascinated by Plant Vascular Biology (PVB) was cordially welcomed to Helsinki, the capital of Finland, to discuss the latest advances in the field. This meeting was the Third International Conference on PVB, following the successful meetings organized in Taiwan and the USA. Approximately 200 scientists from all around the world participated in PVB2013, which was characterized by lively scientific discussions in a relaxed atmosphere. The meeting was rich in topics and disciplines covering vascular biology from the early embryo to the mature plant, from the root tip to aerial organs, all linked by an appreciation of crucial connective role of vascular tissues in plant growth and development. In this report, we briefly summarize some of the contributions presented during PVB2013 focusing on the development of vascular tissues (Fig. 1, Fig. 2). This special issue also collects a number of exciting papers with a central theme of plant vascular development.

The vascular tissues enable land plants to transport water, nutrients, minerals, photoassimilates, signalling molecules, proteins and mRNAs to their sinks or destinations and also act to support the plant body mechanically (Esau, 1965, Eames and MacDaniels, 1947). Three main types of tissue are distinguishable in the vasculature: xylem, phloem and intervening (pro)cambium. Water-conducting xylem consists of dead cells with thick secondary walls that are perforated to connect them to the walls to other vertical xylem elements. Symplasticly connected phloem cells conduct photoassimilates and nutrients, while the (pro)cambium is a meristematic tissue that gives rise to xylem and phloem (Edwards et al., 1992, Esau, 1965, Lucas et al., 2013). In the past few years, our knowledge of how vascular tissues develop, starting from the early embryo, has substantially increased. Dolf Weijers (Wageningen University, The Netherlands) highlighted the specification of embryonic vascular tissue at PVB2013 (Fig. 1). He emphasized the significance of the TMO5-LHW (TARGET OF MONOPTEROS5 - LONESOME HIGHWAY) dimer for pattern formation in the embryo (De Rybel et al., 2013; see also current issue). The interaction of the two proteins in a distinct coexpression domain was shown to regulate periclinal cell divisions in the vascular cylinder. The identification of targets of the TMO5-LHW dimer has helped in elucidating the signalling cascades involved in these periclinal cell divisions; the identity of some of the targets has shed light on how the phytohormones auxin and cytokinin interact in this process. Another report on early vascular development was provided by Hannetz Roschzttardtz (University of Wisconsin-Madison, USA), who presented new 
results concerning cotyledon vein patterning and embryonic provasculature development in the context of leaf venation. He introduced a novel plant-specific gene family involved in vein pattern formation; a detailed report of the discoveries is expected to become public soon.

Several updates regarding xylem development were presented at PVB2013. The first speaker at the meeting, Hiroo Fukuda (University of Tokyo, Japan), talked about the regulation of vascular stem cell maintenance and differentiation by the TDIF-TDR-WOX4 (Tracheary-element Differentiation Inhibitory Factor - TDIF receptor - WUSCHEL-related HOMEOBOX4) module (Hirakawa et al., 2010). He presented recent findings that link brassinosteroid signalling, which is known to promote xylem cell differentiation (Cano-Delgado et al., 2004, Yamamoto et al., 2007), with TDIF-TDR. Turning to the role of protein movement in vascular patterning, Ji-Young Lee (Seoul National University, Korea) presented work showing that the AT-Hook factors AHL3 (AT-HOOK MOTIF NUCLEAR LOCALIZED PROTEIN 3) and AHL4 move from the procambium to xylem precursors in order to restrict xylem proliferation (Zhou et al., 2013). In addition, she identified genes downstream of SHR (SHORTROOT) which regulate asymmetric cell division. Chun-Ming Liu (Chinese Academy of Sciences, China) presented recently published results on xylem differentiation. He showed that EXOTOA1, a gene encoding an exocyst complex subunit, regulates vesicle trafficking in tracheary element differentiation to control the patterning of secondary cell wall thickening in Arabidopsis (Li et al., 2013). exo70a1 mutant plants have a severe phenotype that can be rescued by grafting mutant shoots onto wild-type rootstocks, indicating the importance of tracheary elements in hydraulic transport upwards from roots. In the second part of his talk, he described a new antagonistic peptide technology that allows functional dissection of small peptide hormones (Song et al., 2013). This technique involves the sequential substitution of each amino acid in the peptide followed by a phenotypic analysis of the transgenic plants. Hannele Tuominen (Umeå Plant Science Centre, Sweden) examined modulators of programmed cell death in the xylem to better understand xylem vessel maturation. She presented AtMC9 (METACASPASE9) as one of the modulators regulating the timing of protoxylem maturation (Bollhöner et al., 2013). Regarding root protoxylem development, Bo Ren (Chinese Academy of Sciences, China) talked about a gene family encoding eukaryotic translation initiation factor 5A (eIF5A). He showed that elF5A-2 interacts with the cytokinin receptor CRE1 (CYTOKININ RESPONSE1) and the cytokinin signalling component AHP1 (ARABIDOPSIS HISTIDINE PHOSPHOTRANSFERASE1). This interaction occurs in a cytokinin-dependent manner, thus introducing a novel factor to cytokinin regulation of protoxylem specification in the Arabidopsis root (Ren et al., 2013). The formation of a union at a graft junction provides an opportunity to study the de novo patterning of vasculature and vascular connectivity. Charles Melnyk (University of Cambridge, UK) took advantage of this, using an interesting micrografting technique by which graft junction formation can be monitored using fluorescent reporters and dyes at the microscopic level. The phytohormone auxin has previously been shown to have a role in vascular reconnection during graft-union 
development (Yin et al., 2012), and the current work presented by Melnyk also highlights the importance of hormonal regulation in junction formation.

As indicated above, hormonal regulation is an inseparable aspect of developmental processes. In her keynote talk, Ottoline Leyser (University of Cambridge, UK) provided an update on the auxin transport model in bud outgrowth (Prusinkiewicz et al., 2009), indicating how the PIN auxin efflux carriers modify the auxin transport network. Adding another layer of hormonal regulation, she described how bud outgrowth is also controlled by strigolactones, which influence shoot branching by modulating the auxin status. In a recent publication, Leyser showed that strigolactones enhance the competition between branches by inducing PIN1 depletion from the plasma membrane (Shinohara et al., 2013). Continuing the auxin transport theme, Adam Runions (University of Calgary, Canada) presented an auxin transport model integrating different ways of regulating PIN polarization in Brachypodium distachyon (Prusinkiewicz and Runions, 2012, O'Connor et al., 2014). In this modeling approach, some of PIN transporters are polarized based on the auxin gradient while others are dependent on the auxin flux. This generates convergence points, creating sinks and allowing effective auxin canalization. Moving from the PINs to the ARFs (AUXIN RESPONSE FACTORs), Thomas Berleth (University of Toronto, Canada) showed that removal of domains III and IV of members of the ARF family leads to dominant function in the protein. Expression of a dominant version of MONOPTEROS(MP)/ARF5 in Arabidopsis allowed detailed analysis of its function in, for example, venation (Krogan et al., 2012). Ana Caño-Delgado (Centre de Recerca en Agrigenòmica, Spain), in turn, gave a talk about brassinosteroid function in procambial cell division. Brassinosteroids are known to promote procambial cell division, and her recent work has shown that brassinosteroid signalling is mediated not only by the receptor BRI1 (BRASSINOSTEROID INSENSITIVE1) but also by its homologues BRL1

(BRASSINOSTEROID RECEPTOR-LIKE1) and BRL3, which play a role in root vascular development (Fàbregas et al., 2013). Caño-Delgado plans to focus on understanding the BRL3 signalosome in her future research.

Other plant species, such as trees like Populus or Eucalyptus, show more pronounced secondary growth by vascular proliferation than Arabidopsis. Tree biomass, produced by to some extent massive secondary growth, is an important ecological and economic trait, acting as a major $\mathrm{CO}_{2}$ sink, as well as providing wood for fire, construction and furniture. Several interesting talks at the PVB2013 meeting addressed the topic of vascular development in trees, wood carbon flux and the effects of drought stress (Fig. 2). Rachel Spicer (Connecticut College, USA) talked about the link between primary and secondary vascular development, particularly the importance of auxin-related processes during shoot development in Populus (Spicer et al., 2013, Spicer and Groover, 2010). She proposed that the auxin transport dynamics between the Populus stem and developing leaf primordia may be more complex than has so far been appreciated. The transcriptional regulation of secondary growth and wood production in Populus was outlined by Andrew Groover (US Forest Service, USA). Earlier work described the involvement of certain transcription factors 
such as ARBORKNOX and REVOLUTA in cell differentiation during secondary growth in Populus (Du et al., 2009, Robischon et al., 2011). Future work will use computational and bioinformatic approaches to model the transcriptional networks involved and gain a deeper understanding of the genetic regulation of these processes (Liu et al., 2014; in this issue). Xin-Qiang He (Peking University, China) described anatomical and microarray analyses of secondary vascular tissue regeneration after bark girdling in Populus (Zhang et al., 2011 and in this issue). After bark girdling, new phloem and cambium cells regenerate from differentiating xylem cells in a process that involves epigenetic regulation. Cytokinin and auxin were also highlighted as important players in the regeneration process. Insights into the regulation of vascular development by the RLK-CLE-WOX (RECEPTOR-LIKE KINASE - CLAVATA3/EMBRYO SURROUNDING REGION - WUSCHEL RELATED HOMEOBOX) pathway in trees were presented by Melis Kucukoglu (Swedish University of Agricultural Sciences, Sweden) (Wang et al., 2013). The WOX4 homologues in poplar were shown to strongly influence secondary growth. Furthermore, a positive feedback loop involving PtWOX4, PtCLE41 and PtRLK3 was suggested. Hua Cassan-Wang (University of Toulouse, France) has used different model species such as Arabidopsis and Eucalyptus to identify novel regulators of wood formation (Cassan-Wang et al., 2012; Cassan-Wang et al., 2013). As an example, she presented certain members of the MYB transcription factor family as regulators of secondary cell wall thickening. Secondary growth is regulated not only by transcription, but also by the availability of carbohydrates needed for cellulose synthesis. Totte Niittylä (Umeå Plant Science Centre, Sweden) talked about primary metabolism in tree wood and presented a recent study showing that fructokinase activity is necessary for carbon flux to cellulose in Populus wood (Roach et al., 2012). Another aspect of secondary growth in trees is their reaction to changing environmental conditions. Climate change may be especially challenging to long-living organisms such as forest trees. Sanna Sevanto (Los Alamos National Laboratory, USA) has tackled this theme by investigating how trees die as a result of long-term drought; she recently discovered that mortality under drought stress in pine is due to hydraulic failure or carbon starvation or the combination of both (Sevanto et al., 2013). Carel W. Windt (Forschungszentrum Jülich, Germany) introduced how MRI (Magnetic Resonance Imaging) flowmetry can be used to measure the flow conducting area in herbs and trees (Windt et al., 2009). In his recent research, MRI flowmetry was applied to large potted beech trees, in order to study what fraction of the xylem cross-sectional lumen area conducted flow, how this fraction changed under the influence of prolonged drought, and to measure how much xylem water during this process was released to the tree. The PVB2013 meeting also provided an opportunity to present findings which were atypical or less wellknown. In this spirit, research on the atypical phloem of cucurbits was presented. Unlike most other plants, cucurbits have two types of phloem: fascicular phloem, which is located within the vascular bundles, and extrafascicular phloem in the periphery and scattered throughout other tissues. Rosa Lopez-Cobollo (Imperial College London, UK) used comparative proteomics between two cucurbits, pumpkin and cucumber, and other species with normal phloem to study the function of the unusual phloem of cucurbits 
(Turnbull and Lopez-Cobollo, 2013). Another topic which has not been widely explored is the coordinated development of myrosin cell differentiation and leaf vein patterning. Makoto Shirakawa (Kyoto University, Japan) provided insights into this aspect of leaf vascular network development, presenting evidence for molecular and hormonal regulation of coordinated myrosin differentiation/vein patterning involving vacuolar protein trafficking and endocytosis (Ueda et al., 2006, Shirakawa et al., 2010).

A number of talks dealt with the creation of gene or protein maps and the modeling of regulatory networks. Siobhan Brady (UC Davis, USA) opened the integrative plant vascular biology session by describing gene regulatory networks involved in vascular development. This work, which integrates gene expression and protein-DNA interaction studies in Arabidopsis, broadens our understanding of cell-type specification and proliferation over developmental time (Brady et al., 2011, Gaudinier et al., 2011, Brady et al., 2007). To model secondary xylem and phloem development, Christian Hardtke (University of Lausanne, Switzerland) used a semi-automated approach to generate a cellular atlas of secondary growth in hypocotyls (Ragni et al., 2011 and in this issue). Thomas Greb (Gregor Mendel Institute, Austria) addressed the question of how lateral plant growth is regulated by generating a tissue-specific gene expression map of the Arabidopsis stem and using a forward genetic screen, both targeting meristem initiation in stems (Sanchez et al., 2012 and in this issue). Since lateral growth initiation is regulated by auxin produced in the shoot apex (see e.g. Sanchez et al. 2014 and references therein), this approach is expected to shed light on the mechanisms connecting auxin accumulation and vascular cell division. Anthony Bishopp's (University of Nottingham, UK) talk continued the integrative vascular biology theme by bringing to the fore the interaction between hormonal signalling networks and microRNAs in vascular patterning. Earlier research has described several factors regulating procambial patterning in the Arabidopsis root, including a spatiallyembedded feedback loop between cytokinin and auxin (Bishopp et al., 2011), the mobile transcription factor SHORTROOT, the HD-ZIP IIIs and miRNA165/6 (Helariutta et al., 2000, Prigge et al., 2005, Carlsbecker et al., 2010). Bishopp presented a mathematical model combining these gene regulatory networks to reproduce the observed vascular patterns and predict new phenotypes (Muraro et al., 2014).

Vascular trafficking was the other main topic of the PVB2013 meeting; for a summary of this aspect and interesting contributions of some of the presenters the reader is referred to a special issue of the Journal of Experimental Biology. Overall, the five stimulating days spent at PVB2013 hopefully served as a seed crystal for novel ideas and collaborations, as well as providing a comprehensive overview of the state of plant vascular biology. Integrative networks and models were a prominent part of the many fascinating findings, creating a context for the research by connecting results from throughout the community. We look forward to hearing about more new findings and continuing progress on these hot topics at the next PVB conference to be organized in China in 2016. 


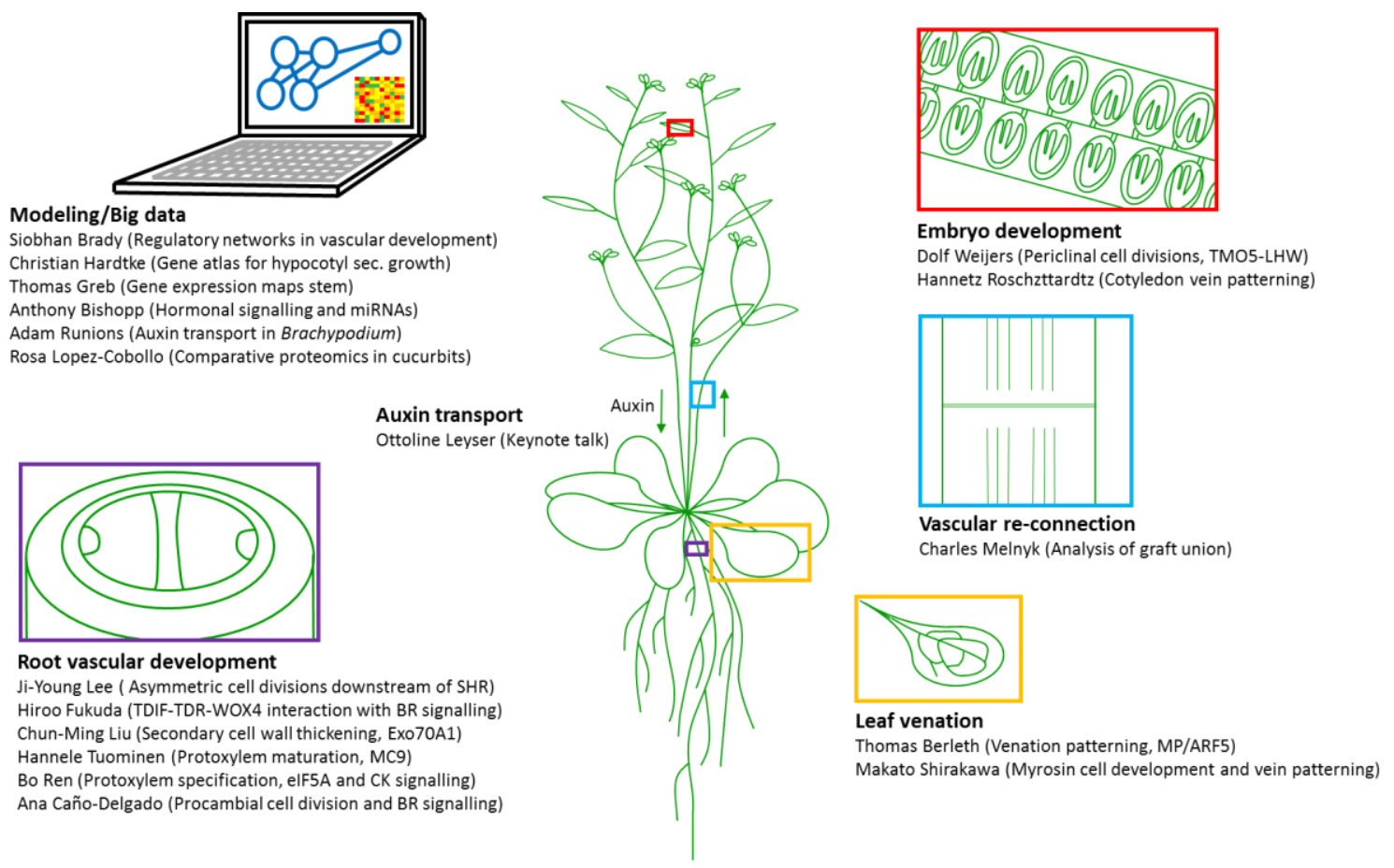

Fig.1

Topics of the PVB 2013 conference concerning Arabidopsis, Big Data and modeling.

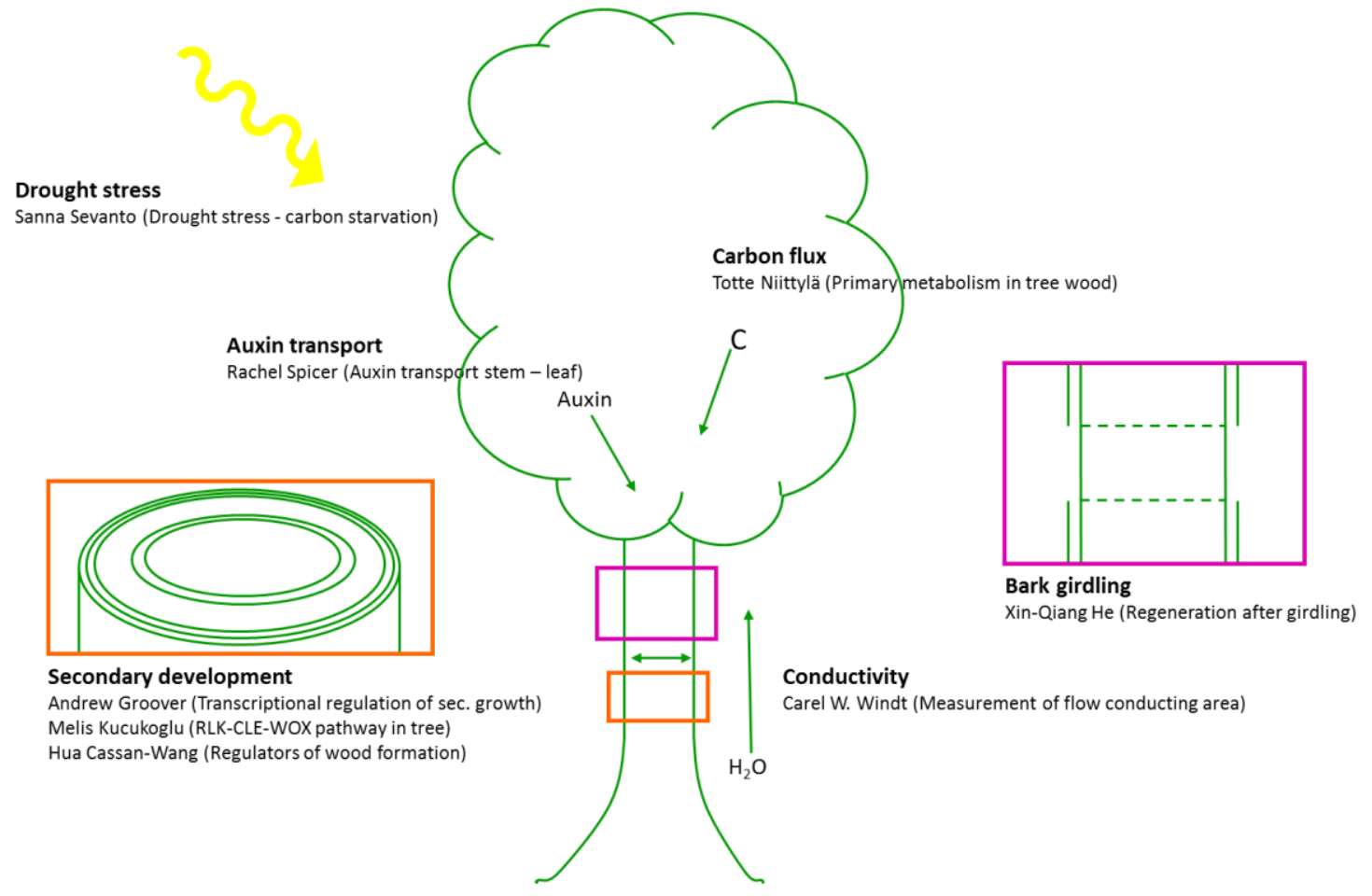

Fig.2

Topics of the PVB 2013 conference concerning trees. 
Acknowledgement

We thank Sedeer El-Showk for proof-reading the manuscript.

BISHOPP, A., HELP, H., EL-SHOWK, S., WEIJERS, D., SCHERES, B., FRIML, J., BENKOVÁ, E., MÄHÖNEN, ARI P. \& HELARIUTTA, Y. 2011. A mutually inhibitory interaction between auxin and cytokinin specifies vascular pattern in roots. Current Biology, 21, 917-926.

BOLLHÖNER, B., ZHANG, B., STAEL, S., DENANCÉ, N., OVERMYER, K., GOFFNER, D., VAN BREUSEGEM, F. \& TUOMINEN, H. 2013. Post mortem function of AtMC9 in xylem vessel elements. New Phytologist, 200, 498-510.

BRADY, S. M., ORLANDO, D. A., LEE, J. Y., WANG, J. Y., KOCH, J., DINNENY, J. R., MACE, D., OHLER, U. \& BENFEY, P. N. 2007. A high-resolution root spatiotemporal map reveals dominant expression patterns. Science, 318, 801-6.

BRADY, S. M., ZHANG, L., MEGRAW, M., MARTINEZ, N. J., JIANG, E., YI, C. S., LIU, W., ZENG, A., TAYLORTEEPLES, M., KIM, D., AHNERT, S., OHLER, U., WARE, D., WALHOUT, A. J. \& BENFEY, P. N. 2011. A stele-enriched gene regulatory network in the Arabidopsis root. Mol Syst Biol, 7, 459.

CANO-DELGADO, A., YIN, Y., YU, C., VAFEADOS, D., MORA-GARCIA, S., CHENG, J. C., NAM, K. H., LI, J. \& CHORY, J. 2004. BRL1 and BRL3 are novel brassinosteroid receptors that function in vascular differentiation in Arabidopsis. Development, 131, 5341-51.

CARLSBECKER, A., LEE, J. Y., ROBERTS, C. J., DETTMER, J., LEHESRANTA, S., ZHOU, J., LINDGREN, O., MORENO-RISUENO, M. A., VATEN, A., THITAMADEE, S., CAMPILHO, A., SEBASTIAN, J., BOWMAN, J. L., HELARIUTTA, Y. \& BENFEY, P. N. 2010. Cell signalling by microRNA165/6 directs gene dosedependent root cell fate. Nature, 465, 316-21.

CASSAN-WANG, H., GOUÉ, N., SAIDI, M. N., LEGAY, S., SIVADON, P., GOFFNER, D. \& GRIMA-PETTENATI, J. 2013. Identification of novel transcription factors regulating secondary cell wall formation in Arabidopsis. Frontiers in Plant Science, 4.

CASSAN-WANG, H., SOLER, M., YU, H., CAMARGO, E. L. O., CAROCHA, V., LADOUCE, N., SAVELLI, B., PAIVA, J. A. P., LEPLÉ, J.-C. \& GRIMA-PETTENATI, J. 2012. Reference genes for high-throughput quantitative reverse transcription-PCR Analysis of gene expression in organs and tissues of Eucalyptus grown in various environmental conditions. Plant and Cell Physiology, 53, 2101-2116.

DE RYBEL, B., MOLLER, B., YOSHIDA, S., GRABOWICZ, I., BARBIER DE REUILLE, P., BOEREN, S., SMITH, R. S., BORST, J. W. \& WEIJERS, D. 2013. A bHLH complex controls embryonic vascular tissue establishment and indeterminate growth in Arabidopsis. Dev Cell, 24, 426-37.

DU, J., MANSFIELD, S. D. \& GROOVER, A. T. 2009. The Populus homeobox gene ARBORKNOX2 regulates cell differentiation during secondary growth. The Plant Journal, 60, 1000-1014.

EAMES, A. J. \& MACDANIELS, L. H. 1947. An introduction to plant anatomy. In: MCGRAW-HILL (ed.) 2nd ed. New York, New York, USA.

EDWARDS, K. L., DAVIES, K. L. \& AXE, L. 1992. A vascular conducting strand in the early land plant Cooksonia. Nature, 357, 683-685.

ESAU, K. 1965. Vascular differentiation in plants, New York, New York, USA.

FÀBREGAS, N., LI, N., BOEREN, S., NASH, T. E., GOSHE, M. B., CLOUSE, S. D., DE VRIES, S. \& CAÑO-DELGADO, A. I. 2013. The BRASSINOSTEROID INSENSITIVE1-LIKE3 signalosome complex regulates Arabidopsis root development. The Plant Cell Online. 
GAUDINIER, A., ZHANG, L., REECE-HOYES, J. S., TAYLOR-TEEPLES, M., PU, L., LIU, Z., BRETON, G., PRUNEDAPAZ, J. L., KIM, D., KAY, S. A., WALHOUT, A. J. M., WARE, D. \& BRADY, S. M. 2011. Enhanced Y1H assays for Arabidopsis. Nat Meth, 8, 1053-1055.

HELARIUTTA, Y., FUKAKI, H., WYSOCKA-DILLER, J., NAKAJIMA, K., JUNG, J., SENA, G., HAUSER, M.-T. \& BENFEY, P. N. 2000. The SHORT-ROOT gene controls radial patterning of the Arabidopsis root through radial signaling. Cell, 101, 555-567.

HIRAKAWA, Y., KONDO, Y. \& FUKUDA, H. 2010. TDIF peptide signaling regulates vascular stem cell proliferation via the WOX4 homeobox gene in Arabidopsis. The Plant Cell Online, 22, 2618-2629.

KROGAN, N. T., CKURSHUMOVA, W., MARCOS, D., CARAGEA, A. E. \& BERLETH, T. 2012. Deletion of MP/ARF5 domains III and IV reveals a requirement for Aux/IAA regulation in Arabidopsis leaf vascular patterning. New Phytologist, 194, 391-401.

LI, S., CHEN, M., YU, D., REN, S., SUN, S., LIU, L., KETELAAR, T., EMONS, A.-M. C. \& LIU, C.-M. 2013. EXO70A1-mediated vesicle trafficking is critical for tracheary element development in Arabidopsis. The Plant Cell Online, 25, 1774-1786.

LUCAS, W. J., GROOVER, A., LICHTENBERGER, R., FURUTA, K., YADAV, S. R., HELARIUTTA, Y., HE, X. Q., FUKUDA, H., KANG, J., BRADY, S. M., PATRICK, J. W., SPERRY, J., YOSHIDA, A., LOPEZ-MILLAN, A. F., GRUSAK, M. A. \& KACHROO, P. 2013. The plant vascular system: evolution, development and functions. J Integr Plant Biol, 55, 294-388.

MURARO, D., MELLOR, N., POUND, M. P., HELP, H., LUCAS, M., CHOPARD, J., BYRNE, H. M., GODIN, C., HODGMAN, T. C., KING, J. R., PRIDMORE, T. P., HELARIUTTA, Y., BENNETT, M. J. \& BISHOPP, A. 2014. Integration of hormonal signaling networks and mobile microRNAs is required for vascular patterning in Arabidopsis roots. Proc Natl Acad Sci U S A, 111, 857-862.

O'CONNOR, D. L., RUNIONS, A., SLUIS, A., BRAGG, J., VOGEL, J. P., PRUSINKIEWICZ, P. \& HAKE, S. 2014. A division in PIN-mediated auxin patterning during organ initiation in grasses. PLoS Comput Biol, 10, e1003447.

PRIGGE, M. J., OTSUGA, D., ALONSO, J. M., ECKER, J. R., DREWS, G. N. \& CLARK, S. E. 2005. Class III homeodomain-leucine zipper gene family members have overlapping, antagonistic, and distinct roles in Arabidopsis development. Plant Cell, 17, 61-76.

PRUSINKIEWICZ, P., CRAWFORD, S., SMITH, R. S., LJUNG, K., BENNETT, T., ONGARO, V. \& LEYSER, O. 2009. Control of bud activation by an auxin transport switch. Proc Natl Acad Sci U S A, 106, 17431-6.

PRUSINKIEWICZ, P. \& RUNIONS, A. 2012. Computational models of plant development and form. New Phytologist, 193, 549-569.

RAGNI, L., NIEMINEN, K., PACHECO-VILLALOBOS, D., SIBOUT, R., SCHWECHHEIMER, C. \& HARDTKE, C. S. 2011. Mobile gibberellin directly stimulates Arabidopsis hypocotyl xylem expansion. The Plant Cell Online, 23, 1322-1336.

REN, B., CHEN, Q., HONG, S., ZHAO, W., FENG, J., FENG, H. \& ZUO, J. 2013. The Arabidopsis eukaryotic translation initiation factor elF5A-2 regulates root protoxylem development by modulating cytokinin signaling. Plant Cell, 25, 3841-3857.

ROACH, M., GERBER, L., SANDQUIST, D., GORZSÁS, A., HEDENSTRÖM, M., KUMAR, M., STEINHAUSER, M. C., FEIL, R., DANIEL, G., STITT, M., SUNDBERG, B. \& NIITTYLÄ, T. 2012. Fructokinase is required for carbon partitioning to cellulose in aspen wood. The Plant Journal, 70, 967-977.

ROBISCHON, M., DU, J., MIURA, E. \& GROOVER, A. 2011. The Populus class III HD ZIP, popREVOLUTA, influences cambium initiation and patterning of woody stems. Plant Physiology, 155, 1214-1225.

SANCHEZ, P., NEHLIN, L. \& GREB, T. 2012. From thin to thick: major transitions during stem development. Trends in Plant Science, 17, 113-121.

SEVANTO, S., MCDOWELL, N. G., DICKMAN, L. T., PANGLE, R. \& POCKMAN, W. T. 2013. How do trees die? A test of the hydraulic failure and carbon starvation hypotheses. Plant, Cell \& Environment, n/a-n/a.

SHINOHARA, N., TAYLOR, C. \& LEYSER, O. 2013. Strigolactone can promote or inhibit shoot branching by triggering rapid depletion of the auxin efflux protein PIN1 from the plasma membrane. PLoS Biol, 11, e1001474.

SHIRAKAWA, M., UEDA, H., SHIMADA, T., KOUMOTO, Y., SHIMADA, T. L., KONDO, M., TAKAHASHI, T., OKUYAMA, Y., NISHIMURA, M. \& HARA-NISHIMURA, I. 2010. Arabidopsis Qa-SNARE SYP2 proteins 
localized to different subcellular regions function redundantly in vacuolar protein sorting and plant development. The Plant Journal, 64, 924-935.

SONG, X.-F., GUO, P., REN, S.-C., XU, T.-T. \& LIU, C.-M. 2013. Antagonistic peptide technology for functional dissection of CLV3/ESR genes in Arabidopsis. Plant Physiology, 161, 1076-1085.

SPICER, R. \& GROOVER, A. 2010. Evolution of development of vascular cambia and secondary growth. New Phytologist, 186, 577-592.

SPICER, R., TISDALE-ORR, T. \& TALAVERA, C. 2013. Auxin-responsive DR5 promoter coupled with transport assays suggest separate but linked routes of auxin transport during woody stem development in Populus. PLOS ONE, 8, e72499.

TURNBULL, C. G. N. \& LOPEZ-COBOLLO, R. M. 2013. Heavy traffic in the fast lane: long-distance signalling by macromolecules. New Phytologist, 198, 33-51.

UEDA, H., NISHIYAMA, C., SHIMADA, T., KOUMOTO, Y., HAYASHI, Y., KONDO, M., TAKAHASHI, T., OHTOMO, I., NISHIMURA, M. \& HARA-NISHIMURA, I. 2006. AtVAM3 is required for normal specification of idioblasts, myrosin cells. Plant and Cell Physiology, 47, 164-175.

WANG, J., KUCUKOGLU, M., ZHANG, L., CHEN, P., DECKER, D., NILSSON, O., JONES, B., SANDBERG, G. \& ZHENG, B. 2013. The Arabidopsis LRR-RLK, PXC1, is a regulator of secondary wall formation correlated with the TDIF-PXY/TDR-WOX4 signaling pathway. BMC Plant Biol, 13, 94.

WINDT, C. W., GERKEMA, E. \& VAN AS, H. 2009. Most water in the tomato truss is imported through the xylem, not the phloem: A nuclear magnetic resonance flow imaging study. Plant Physiology, 151, 830-842.

YAMAMOTO, R., FUJIOKA, S., IWAMOTO, K., DEMURA, T., TAKATSUTO, S., YOSHIDA, S. \& FUKUDA, H. 2007. Co-regulation of brassinosteroid biosynthesis-related genes during xylem cell differentiation. Plant and Cell Physiology, 48, 74-83.

YIN, H., YAN, B., SUN, J., JIA, P., ZHANG, Z., YAN, X., CHAI, J., REN, Z., ZHENG, G. \& LIU, H. 2012. Graft-union development: a delicate process that involves cell-cell communication between scion and stock for local auxin accumulation. $J$ Exp Bot, 63, 4219-32.

ZHANG, J., GAO, G., CHEN, J.-J., TAYLOR, G., CUI, K.-M. \& HE, X.-Q. 2011. Molecular features of secondary vascular tissue regeneration after bark girdling in Populus. New Phytologist, 192, 869-884.

ZHOU, J., WANG, X., LEE, J. Y. \& LEE, J. Y. 2013. Cell-to-cell movement of two interacting AT-hook factors in Arabidopsis root vascular tissue patterning. Plant Cell, 25, 187-201. 